\title{
SAUGESNIO IR VEIKSMINGESNIO PACIENTU TARPSTACIONARINIO TRANSPORTAVIMO PRINCIPAI
}

\author{
Gintautas Virketis ${ }^{1}$, Eglė Krūminytè ${ }^{2}$ \\ ${ }^{1}$ Klaipeddos universitetine ligonine, Klaipèdos universitetas, \\ ${ }^{2}$ Lietuvos sveikatos mokslu universiteto ligoniné Kauno klinikos, Psichiatrijos klinika
}

Raktažodžiai: tarpstacionarinis transportavimas, tretinis tarpstacionarinis pacientų transportavimas, standartizuotas paciento būklès vertinimo protokolas.

\begin{abstract}
Santrauka
Pacientų tarpstacionarinis transportavimas - tai populiari medicininès priežiūros priemonè, plačiai taikoma daugelyje šalių, tarp jų ir Lietuvoje. Tai atskira sveikatos priežiūros paslaugų veikla, pagrịsta užsienio moksliniuose tyrimuose, tačiau Lietuvoje nežinomas jos mastas, su kokiomis kliūtimis susiduriama, kokios reikalingos sąlygos. Šiame straipsnyje aptariami tarpstacionarinio transportavimo principai, užtikrinantys sklandų ir saugų pacientų transportavimo mechanizmą tarp skirtingų lygių asmens sveikatos priežiūros ịstaigų.

Darbo tikslas - išsiaiškinti ir ịvertinti greitosios medicinos pagalbos ir stacionarinių sveikatos priežiūros įstaigų vadovų bei specialistų nuomonę apie esamą pacientų tarpstacionarinių transportavimų situaciją Lietuvoje ir veiksmus, galinčius paskatinti veiksmingesnị ir saugesnị pacientų tarpstacionarinị transportavimą.

Tyrimo kontingentas ir metodika. Atliktas kiekybinis tyrimas anketinès apklausos metodu. Apklausta 118 respondentų. Respondentais pasirinkti stacionarinių asmens sveikatos priežiūros ịstaigų ir greitosios medicinos pagalbos ịstaigų vadovai, reanimacijos ir intensyviosios terapijos skyrių (RITS) vadovai / vedèjai bei prièmimo skubios pagalbos skyrių vedèjai. Rezultatai ir jų aptarimas. 83,9 proc. respondentu teigia, kad pacientams perkelti iš vienos ligoninès i kitą standartizuotų būklès vertinimo protokolų nèra. 53 proc. respondentu pritaria, kad tokie protokolai būtų paruošti ir taikomi. Atsakymo, kad „Siunčiančiosios įstaigos gydytojas" atsakingas už sprendimo prièmimą dèl paciento transportavimo, variantų vidurkis statistiškai labai reikšmingai didesnis už vi-
\end{abstract}

sus likusius atsakymų variantų vidurkius. Daugiau nei du trečdaliai atsakiusiujų (68,6 proc.) mano, kad paciento (atstovo) sutikimas transportuoti ị kitą ligoninę būtinas. 73,1 proc. respondentų pritaria, kad po skubios medicinos pagalbos (SMP) paslaugų suteikimo tikslingas tolimesnio pacientų transportavimo gydymui užbaigti pagal gyvenamają vietą teisinis reglamentavimas. 45,2 proc. pritaria, kad transportavimus turètų vykdyti greitosios medicinos pagalbos (GMP) tarnyba. Kad „už pacientų tarpstacionarini transportavimą tarp įstaigų gydymo užbaigimui pagal gyvenamają vietą po SMP paslaugų suteikimo“ turètų būti apmokama iš PSDF biudžeto, pasisako 87,5 proc. respondentų.

Išvados. Standartizuoto paciento būklès vertinimo protokolo įdiegimas užtikrintų saugesni pacientų tarpstacionarinị transportavimą. Siunčiantis gydytojas atsakingas už paciento transportavimo poreikio nustatymą. Pacientas ar jo atstovas turi būti pasirašytinai supažindintas su numatomu transportavimu. Tarpstacionarinio transportavimo paslauga turètų būti reglamentuota ir atskirai apmokama iš PSDF biudžeto.

\section{Ivadas}

Tarpstacionarinis transportavimas (TT) daugeliui pacientų tapo kasdienine ir neatsiejama sveikatos priežiūros paslaugų dalimi ne tik dèl didesnių galimybių gauti specializuotą gydymą ar diagnostines procedūras aukštesnio ar aukščiausio lygio sveikatos priežiūros paslaugas teikiančiose gydymo instaigose, bet ir baigti gydymą arčiau namų esančiose asmens sveikatos priežiūros ịstaigose [1]. Pacientų transportavimas laikomas viena iš pagrindinių veiklų, turinčių didelę ịtaką sveikatos priežiūroje [2]. Pacientams, sergantiems lètinèmis ligomis, TT suteikia nuolatinę sveikatos priežiūrą bei galimybę laikytis kintančios gydymo taktikos, vadovaujantis irodymais pagrịsta medicina $[3,4]$.

Remiantis moksliniais šaltiniais [1], apie 5 proc. pacientų, gaunančių sveikatos priežiūros paslaugas, yra trans- 
portuojami i atitinkamo lygio gydymo įstaigas. Jungtinèse Amerikos Valstijose ir Jungtinèje Karalysteje TT taikomas 1 iš 20 pacientų [5]. Lietuvoje tarpstacionarinio transportavimo problematika jau yra diskutuota [6], tačiau tikslios transportuojamų pacientų apimtys, priežastys, pasekmès mokslininkams, sveikatos vadybininkams ir paslaugų teikèjams nèra žinomos ir mokslinèje literatūroje dar nėra plačiau išnagrinètos. Tikètina, kad Lietuvos gydymo įstaigose, inicijuojant TT, vis dar išlieka problema dèl neaiškaus ir neapibrezžto pacientų transportavimo.

Mokslinėje literatūroje, apžvelgiant saugius TT vykdymo principus [7-10], autoriai rekomenduoja naudotis standarizuotais paciento būklès vertinimo protokolais ar pacientu perkèlimo formomis bei reikalinga dokumentacija, norint užtikrinti adekvatų pacientų transportavimą [11]. Kritinès medicininès priežiūros asociacija (SCCM), Europos intensyviosios medicininès priežiūros asociacija (ESICM), Australijos - Azijos skubiosios medicininés pagalbos kolegija bei JAV kvėpavimo priežiūros asociacija 2005 metais, remdamiesi atitinkamomis nuostatomis, išleido gaires dèl efektyvaus tarpstacionarinio transportavimo vykdymo užtikrinimo [12]. Vadovaujantis rekomendacijomis, kiekviena ligonine turi remtis TT standarizuotais protokolais, sudarytais daugiaprofilinès gydytojų komandos bei atitikti kokybę įrodančius reikalavimus. Nurodoma, kad protokole turi atsispindèti: klinikinè paciento būklè, prieštransportacinio tarpstacionarinio bendravimo principai, reikalinga įranga bei pacientų būklès monitoriavimo aspektai $[12,13]$. Prieš transportuojant pacientą, turi būti užpildyta dokumentacija, kurioje būtų ịtraukta paciento perkèlimo sutikimo forma bei tolimesnès pervežimo koordinatès [13]. 2011 metais ịvairios tarptautinès organizacijos (American College of Critical Care Medicine and Society of Critical Care Medicine, American College of Emergency Physicians, Australasian College of Emergency Medicine, Intensive Care Society and Faculty of Intensive Care of the Australian and New Zealand College of Anaesthetists) suformulavo atnaujintas gaires norintiems sinchronizuoti TT vykdymą savo šalyse. Gairèse daugiausia akcentuojamas prieštransportacinis komunikavimas, kvalifikuotas lydintis personalas, tinkama transportavimo įranga bei pabrèžiama dokumentacijos svarba, kaip raktas ị saugų pacientų transportavimą [14]. Mokslinių straipsnių autoriai teigia, kad vadovaujantis standarizuotu TT protokolu, minimalizuojamos galimos komplikacijos bei išvengiama apie 70 proc. nepalankių įvykių vykdant pacientų transportavimą [15].

Paskutiniame dešimtmetyje didelis dèmesys buvo skiriamas antriniam pacientų transportavimui [1,6, 15-17]. Tačiau didžiają transportuojamų pacientų dalį sudaro nekritinès būklès ligoniai, reikalaujantys tretinio TT, kuris, pasak mokslinių tyrimų, reikšmingai didèja [18-20]. Pavyzdžiui, 2007-2008 metais Australijos vyriausybè išleido apie 2 bilijonus Australijos dolerių tretiniam pacientų TT vykdymui, o metinis šių paslaugų augimas siekè 8.5 proc. [2]. 2016 metais JAV atliktame tyrime, kuriame dalyvavo 32 valstijos, paaiškejjo, kad daugiau nei 50 proc. pacientų buvo suteikta tretinio TT paslauga [20]. Lietuvoje tretinio TT problema taip pat aktuali [6]. Gausejjančias tretinio TT paslaugas Lietuvoje dar paskatino nuo $2016 \mathrm{~m}$. lapkričio 1 d. įsigaliojusi Sveikatos apsaugos ministro nustatyta tvarka dèl tęstinio aktyvaus gydymo paslaugų teikimo [21]. Šioje tvarkoje nurodoma, kad dèl tos pačios ligos ar būklès, dèl kurios pacientai buvo gydomi respublikos lygmens asmens sveikatos priežiūros įstaigose (toliau-ASPĮ) (įskaitant ir universitetines ligonines), po užbaigto stacionarinio gydymo aktyvus stacionarinis gydymas turi būti tęsiamas regiono ar rajono lygmens ASPI.

Tačiau analizuojant tretinio TT vykdymą Lietuvoje susiduriama su šios paslaugos organizavimo, teikimo ir finansavimo problemomis. Ketvirtame sveikatos sistemos pletros ir ligoninių tinklo konsolidavimo etape pagal įvardytas restruktūrizavimo kryptis vienu iš prioritetų numatytas ,pacientų transportavimo sistemos tobulinimas ir pervežimo ịkainių reglamentavimas" [22]. Šiuo metu už pacientų transportavimą apmokama tik atskirais atvejais, kai transportavimą atlieka greitosios medicinos pagalbos tarnyba pagal atskirą tvarką [23].

Darbo tikslas: išsiaiškinti ir ịvertinti greitosios medicinos pagalbos ir stacionarinių sveikatos priežiūros ịstaigų vadovų bei specialistų nuomonę apie esamą pacientų tarpstacionarinių transportavimų situaciją Lietuvoje ir veiksmus, galinčius paskatinti veiksmingesnị ir saugesnị pacientų tarpstacionarinị transportavimą.

\section{Darbo objektas ir metodika}

Atliktas kiekybinis tyrimas anketinès apklausos metodu. Anketos sudarytos vieno iš autorių ${ }^{1}$. Respondentais pasirinkti stacionarinių asmens sveikatos priežiūros ịstaigų ir greitosios medicinos pagalbos ịstaigų vadovai, reanimacijos ir intensyviosios terapijos skyrių (RITS) vadovai / vedèjai bei prièmimo skubios pagalbos skyrių vedejjai. Respondentų apklausa vykdyta 2015-02-13 - 2015-04-20 internetinés apklausos metodu. Tiriamujų imtis turéjo būti 117 ar daugiau asmenų, kad būtų galima padaryti statistiškai reikšmingas išvadas. Anketas tinkamai užpildè 118 respondentų. Anketų duomenų analizei naudota SPSS 21 programa. Statistineje analizėje ryšiai tarp nominalinių požymių vertinti chi kvadrato $(\chi 2)$ kriterijumi, tarp intervalinių kintamujų - vidurkių lyginimo statistiniais metodais. Statistiškai reikšmingam rezultatų skirtumui ịvertinti pasirinktas $p<0,05$, statistiškai 
labai reikšmingam $-p<0,01$ lygmuo. Atsakymų variantai, pateikti Likerto (Likert) tipo skalèse, apskaičiuoti kaip 5 balu sistemos vertinimo vidurkiai, kur 1 balas atitinka priešingą reikšmę 5 balams, o atsakymų variantai Nr. 6 , atitinkantys reikšmę „nežinau“, interpretuoti kaip ị klausimą „,neatsakyta“.

\section{Rezultatai ir jų aptarimas}

Ivertinus analizuotas problemas, buvo atliktas tyrimas, norint išsiaiškinti ASPI darbuotojų nuomonių pasiskirstymą dèl standarizuoto pacientų būklès vertinimo protokolo įdiegimo ASPI , reikalingos dokumentacijos vykdant tarpstacionarinį transportavimą, ịtraukiant ir tretinio TT vykdymą bei jo finansavimą.

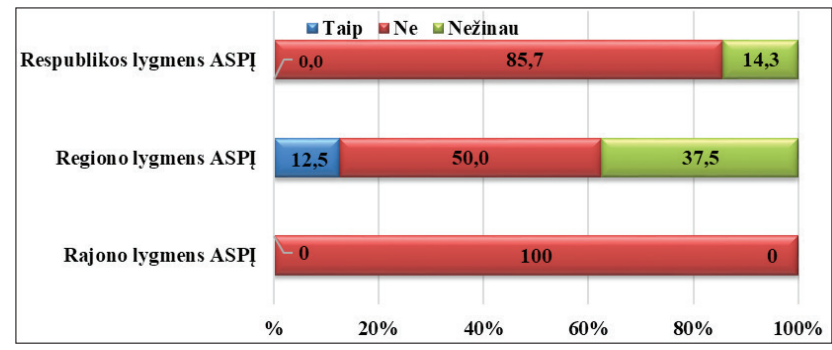

1 pav. Nuomonių dèl ị kitą ligoninę perkeliamų pacientų standartizuotų būklès vertinimo protokolų buvimas pagal ASPI lygmeni skirstinys, proc.

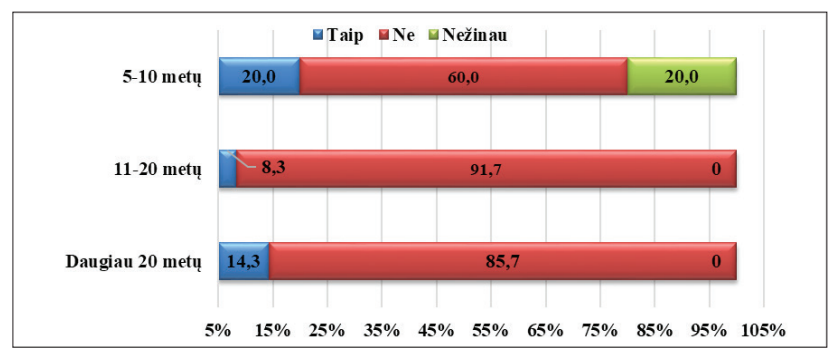

2 pav. Nuomonių dèl ị kitą ligoninę perkeliamų pacientų standartizuotų būklès vertinimo protokolų buvimo pagal stažą skirstinys, proc.

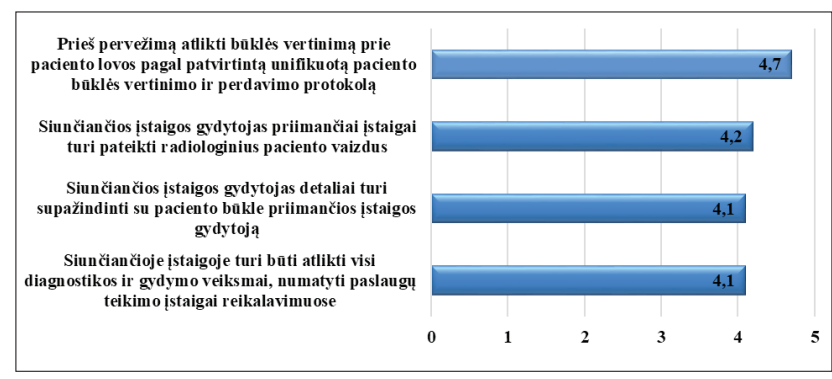

3 pav. Veiksmų, siūlomų atlikti prieš paciento transportavimą, vertinimo vidurkiai, balais
Prieš atliekant pacientų transportavimą iš vienos stacionarines paslaugas teikiančios gydymo ịstaigos ị kitą, svarbus paciento būklès ịvertinimas. Nevienodas paciento būklès vertinimas svarbus siunčiančiai ir priimančiai gydymo įstaigoms šiais aspektais: pacientą norint perkelti į aukštesnio lygio paslaugas teikiančią ligoninę, siunčiančios ligoninès gydytojai paciento būklę gali vertinti kaip sunkesnę, neatitinkančią tos gydymo įstaigos teikiamų paslaugų lygio, todèl nesuteikus paslaugų pagal patvirtintus paslaugų teikimo reikalavimus savo gydymo ịstaigoje, pervežti pacientą i kitą ligoninę. Priimančios aukštesnio lygio stacionarines paslaugas teikiančios gydymo ịstaigos gydytojai paciento būklę gali vertinti kaip lengvesnę ir uždelsti teikiant SMP. Veidrodinis šios problemos atspindys pasireiškia taip: aukštesnio lygio ligoninė po ištyrimo ar gydymo grąžina pacientą gydytis pagal gyvenamają vietą, motyvuodama gerejjančia ir stabilia paciento būkle, nesant poreikio sudètingiems tyrimams ir procedūroms, tačiau žemesnio lygio gydymo ịstaigoms paciento būklè vis tiek atrodo per ,sunki““.

Dominuoja nuomonè ( 83,9 proc.), kad pacientams perkelti iš vienos ligoninès ị kitą standartizuotų būklès vertinimo protokolų nèra. Rezultatai nesiskiria statistiškai reikšmingai atsižvelgiant ị respondentų amžių, lytị, ASPI steigèją, ASPI specialistų tipą, tačiau skiriasi statistiškai reikšmingai $\left(\chi^{2}\right.$ kriterijus, $\mathrm{p}<0,05)$ atsižvelgiant ị ASPİ lygmenị ir stažą.

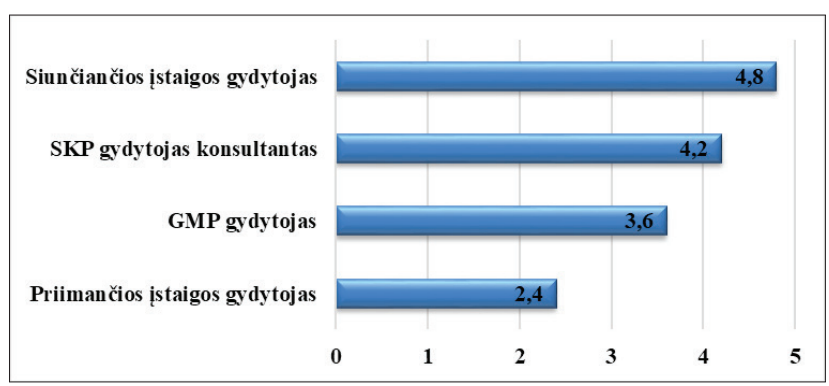

4 pav. Vertinimų dèl atsakingo asmens sprendimo ir atsakomybès dèl paciento transportavimo priemimo vidurkiai, balais

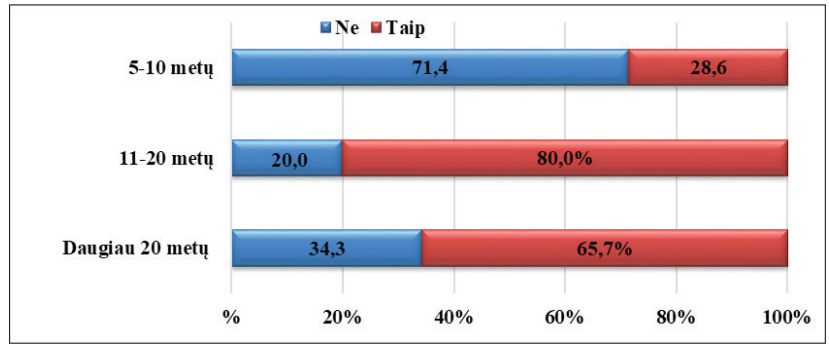

5 pav. Respondentų nuomonių dèl paciento (atstovo) sutikimo transportuoti ị kitą ligoninę būtinumo atsižvelgiant ị darbuotojų stažą pasiskirstymas, proc. 
Nuomonių skirstinys pagal ASPI lygmenị pateikiamas 1 pav.

Kaip matoma iš pateikto grafiko, visi (100 proc.) rajono lygmens ASPI respondentai patvirtina, kad nèra pacientų perkèlimo iš vienos ligoninès ị kitą ligoninę standartizuotų paciento būklès vertinimo protokolų. Didžioji dalis respublikos lygmens ASPI respondentų ( 85,7 proc.) taip pat pritaria tokių protokolų nebuvimui. Tarp regiono lygmens ASPI respondentų taip manančių yra kur kas mažiau - tik pusè (50 proc.). Tačiau dar 37,5 proc. regiono atstovų nežino, ar yra tokie protokolai.

Rezultatai taip pat skiriasi statistiškai reikšmingai $\left(\chi^{2}\right.$ kriterijus, $\mathrm{p}<0,05)$ atsižvelgiant ị respondentų stažą. Nuomonių skirstinys pateiktas 2 pav.

Kaip matyti iš pateikto grafiko, nuomonei, jog nèra pacientų perkèlimo iš vienos ligoninès ị kitą standartizuotų paciento būklès vertinimo protokolų, pritaria beveik visi 11-20 metų darbo stažą turintys darbuotojai (91,7 proc.). Mažiausiai (60 proc.) tam pritaria 5-10 metų darbo stažą turintys respondentai. Galimai kai kurios ASPI yra parengusios lokalius protokolus, nes bendrai patvirtintų rekomendacinio pobūdžio protokolų nèra.

Tyrimo duomenys rodo, kad nesant standartizuoto būklès vertinimo protokolo sudètinga pacientą perkelti ị aukštesnio lygmens sveikatos priežiūros paslaugas teikiančią ASPĮ. Taip pat sudètinga grąžinti pacientą iš respublikos lygmens ị regiono ar rajono lygmens gydymo įstaigą, nežiūrint to, kad diagnozė aiški ir reikalingas tik gydymo tęsimas. Dažniausias atsisakymo motyvas, kad paskirtas gydymas per brangus, reikalingos specialistų konsultacijos, kurių šiose gydymo ịstaigose nèra. Standartizuotų protokolų dèl paciento būklès perkèlimo iš vienos gydymo ịstaigos ị kitą nebuvimas sąlygoja uždelstą diagnostiką ir neefektyvų gydymą, nepagrịstus ilgesnius lovadienius, konfliktines situacijas tiek tarp skirtingų ASPI medicinos personalo, tiek ir su pacientu bei jo artimaisiais.

Norint užtikrinti sklandų paciento transportavimo procesą, reikalinga atlikti tam tikrus paruošiamuosius veiksmus (3 pav.).

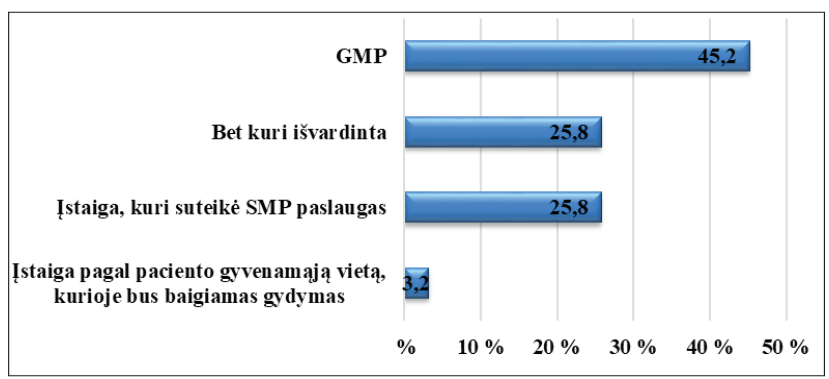

6 pav. Nuomonių dèl pacientų transportavimą turinčios atlikti įstaigos pasiskirstymas, proc.
Kaip matyti iš pateikto grafiko, didžiausią vertinimų vidurkị (4,7 -+ 0,54SD) atitinka atsakymas „Prieš pervežimą atlikti būklès vertinimą prie paciento lovos pagal patvirtintą unifikuotą paciento būklès vertinimo ir perdavimo protokolą“. Šio atsakymo vidurkis statistiškai reikšmingai didesnis už visus likusius atsakymų variantų vidurkius (t-testas priklausomoms imtims, $p<0,01)$. Nors rezultatai statistiškai reikšmingai nesiskiria pagal socialines - demografines bei darbines - organizacines charakteristikas, tačiau už tai, kad prieš pervežimą būtų atliktas būklès vertinimas prie paciento lovos pagal patvirtintą unifikuotą paciento būklès vertinimo ir perdavimo protokolą pasisako daugiau nei du trečdaliai ( 68,8 proc.) stacionarinių asmens sveikatos priežiūros ịstaigų vadovų.

Perkeliant pacientą iš vienos gydymo ịstaigos ị kitą kyla ìvairių ne tik medicininių, bet ir organizacinių, teisinių bei finansinių klausimų. Standartizuoto protokolo taikymas padètų išspręsti nemažai šių problemų. Mūsų tyrimo metu buvo siekiama sužinoti respondentų nuomonę apie perkeliamo paciento būklès vertinimo standartizuoto protokolo poreikio tikslingumą. Kiek daugiau nei pusė respondentų (53 proc.) pritaria, kad tokie protokolai būtu paruošti ir taikomi. Mažiau nei pusė respondentų (47 proc.) tokių protokolų ruošimui nepritaria. Rezultatai nesiskiria statistiškai reikš-

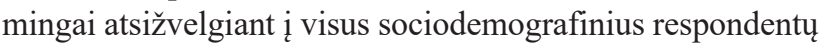
parametrus ( $\chi^{2}$ kriterijus, $\left.p<0,05\right)$. Labiausiai perkeliamo paciento būklès vertinimo standartizuoto protokolo ịvedimui Lietuvoje pritaria respublikos lygmens ASPI atstovai $(64,3$ proc.), kiek mažiau rajono (46,7 proc.) ir mažiausiai regiono ASPI atstovai (40,9 proc.).

Sprendimo prièmimas ir atsakomybės prisièmimas dèl paciento transportavimo poreikio ir būklès pakitimų (galimų pablogèjimų) transportavimo metu yra diskusinis klausimas, kadangi tame procese dalyvauja skirtingu i̇staigų atstovai, turintys ịtakos sklandžiam transportavimo užtikrinimui, arba priešingai, îvertinus esamą situaciją, neleisti atlikti transportavimo esant netransportabiliai paciento būklei (3 pav.).

Kaip matyti pateiktoje diagramoje, didžiausią vertinimo

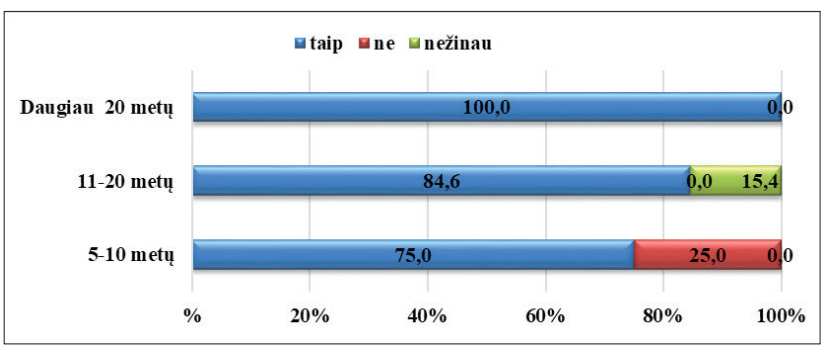

7 pav. Nuomonių dèl tarpstacionarinio transportavimo apmokejjimo iš PSDF biudžeto skirstinys atsižvelgiant ị darbuotojų stažą, proc. 
vidurkị $(4,8 \pm 0,83 \mathrm{SD})$ atitinka atsakymas „Siunčiančiosios ìstaigos gydytojas". Šio atsakymo variantų vidurkis statistiškai labai reikšmingai didesnis už visus likusius atsakymų variantų vidurkius (t-testas priklausomoms imtims, $\mathrm{p}<0,01$ ). Respondentų atsakymų i ši klausimą nuomonès skiriasi statistiškai reikšmingai, atsižvelgiant į ASPI specialistų tipą ir stažą $\left(\chi^{2}\right.$ kriterijus, $\left.p<0,05\right)$. Kad už sprendimo ir atsakomybès priemimą dèl paciento transportavimo atsakingas siunčiantysis gydytojas, daugiausia pasisako reanimacijos ir intensyviosios terapijos skyrių vadovai ( 75,8 proc.), mažiausiai tam pritaria tik kiek daugiau nei trečdalis $(40,6$ proc.) stacionarinių asmens sveikatos priežiūros įstaigos vadovų. Ir priešingai - kad už sprendimo ir atsakomybès prièmimą dèl paciento transportavimo atsakingas priimančiosios ịstaigos gydytojas, daugiausia pasisako stacionarinių asmens sveikatos priežiūros ịstaigų vadovai ( 58,1 proc.), tam pritaria tik mažiau nei trečdalis (27,3 proc.) reanimacijos ir intensyviosios terapijos skyrių vadovų. Daugiau nei du trečdaliai respondentų (69,7 proc.), kurių darbo stažas daugiau nei 20 metų, pasisako kad SKP gydytojas - konsultantas atsakingas už sprendimo ir atsakomybès prièmimą dèl paciento transportavimo, mažiausiai $(28,6$ proc.) tam pritaria respondentai nuo 5 iki 10 metų.

Prieš teikiant medicininę pagalbą, gydytojai daugeliu atvejų yra ịpareigoti gauti paciento ar jo atstovo sutikimą. Tai ypač aktualu esant nesąmoningam pacientui. Paciento teisių ir žalos sveikatai atlyginimo ịstatyme įtvirtinta nuostata, kad būtinas paciento ar jo atstovo supažindinimas su išrašymo ar perkèlimo tolimesniam gydymui ị kitą ASPİ bei paciento (atstovo) sutikimas. Nuomonių, ar būtinas paciento (atstovo) sutikimas transportuoti ị kitą ligoninę, sklaida pateikta 4 paveiksle.

Daugiau nei du trečdaliai atsakiusiujjų ( 68,6 proc.) mano, $\mathrm{kad}$ „taip“, t. y. paciento (atstovo) sutikimas transportuoti i kitą ligoninę būtinas. Trečdalis respondentų nepritaria šiai juridinei nuostatai. Rezultatai nesiskiria statistiškai reikšmingai atsižvelgiant ị respondentų amžių, lytị, SPI steigeją̨, PSP specialistų tipą ir SPI lygmenį, tačiau skiriasi statistiškai reikšmingai $\left(\chi^{2}\right.$ kriterijus, $\left.\mathrm{p}<0,05\right)$ atsižvelgiant ị stažą. Kaip matyti pateikiamoje diagramoje (4 pav.), nuomonei, jog ,paciento (atstovo) sutikimas transportuoti i kitą ligoninę būtinas" dažniau nei kitų tipų specialistai ( 80,0 proc.) pritaria 11-20 metų darbo stažą turintys darbuotojai. Tačiau didžioji dalis (71,4 proc.) 5-10 metų darbo stažą turinčių respondentų ir daugiau nei trečdalis (34,3 proc.) daugiau kaip 20 metu darbo stažą turinčių darbuotojų nepritaria šiuo metu galiojančiai juridinei nuostatai dèl paciento sutikimo transportuoti pacientą ị kitą ligoninę būtinumo. Nepritarimas šiai juridinei nuostatai yra išraiška didelio pacientų skaičiaus transportavimo iš rajono ir regiono lygmens ligoninių i respublikos lygmens ligonines be suderinimo su priimančiaja ịstaiga, motyvuojant sunkia paciento būkle, dažniausiai popietinėmis valandomis ir savaitgaliais. Tokiais atvejais medicininiuose dokumentuose dažniausiai nebūna pažymėta, kad pacientas sutinka būti vežamas ị kitą gydymo įstaigą.

Daugiau nei du trečdaliai $(73,1$ proc.) respondentų pritaria, kad po SMP paslaugų suteikimo stacionare ar PSPS, tikslingas tolimesnis pacientų transportavimas tarp ASPI gydymui užbaigti pagal gyvenamają vietą teisinis reglamentavimas. Rezultatai nesiskiria statistiškai reikšmingai atsižvelgiant ị visas sociodemografines respondentų charakteristikas - amžių, lytį, SPI steigèją, PSP specialistų tipą, SPI lygmenị ir darbo stažą ( $\chi^{2}$ kriterijus $(p>0,05)$. Pacientų transportavimo reglamentavimui labiausiai pritaria stacionarinių ASPI vadovai (81,3 proc.), kiek mažiau RITS vadovai (65,7 proc.) Likusieji kiek daugiau nei penktadalis tokiam reglamentavimui nepritaria (17,9 proc.) arba nežino, kokios nuomonès laikytis šiuo klausimu.

Nors jau reglamentuotas tęstinio aktyvaus gydymo paslaugų teikimas [21], tačiau pacientų transportavimas tarp ASPI gydymui užbaigti pagal gyvenamają vietą po SMP paslaugų suteikimo nèra reglamentuotas. Nèra aišku, kas ir kieno lèšomis turi atlikti tarpstacionarinị transportavimą (6 pav.).

Maždaug pusė respondentų (45,2 proc.) pritaria, kad transportavimus turètų vykdyti GMP tarnyba. Daugiau nei ketvirtis respondentu $(25,8$ proc.) mano, kad tokius transportavimus turi atlikti ịstaiga, kuri suteikè SMP paslaugas, tokia pat dalis ( 25,8 proc.) respondentu pasisako už tai, kad transportavimą gali atlikti tiek GMP, tiek ir ịstaiga, kuri suteikè SMP paslaugas. Tik labai nedidelè dalis (3,2 proc.) respondentų mano, kad pacientą turètų parsivežti ịstaiga pagal paciento gyvenamają vietą, kurioje bus baigiamas gydymas. Rezultatai nesiskiria statistiškai reikšmingai atsižvelgiant i visas sociodemografines respondentų charakteristikas amžiu , lytị, SPI steigèją, PSP specialistų tipą, SPI lygmenị ir darbo stažą ( $\chi^{2}$ kriterijus, $\left.p>0,05\right)$. Labiausiai mano esant tikslinga panaudoti GMP pacientų pervežimams atlikti regiono lygmens ASPI atstovaujantys respondentai (62,5 proc.), mažiausiai respublikos lygmens ( 25 proc.).

$\mathrm{Kad}$,už pacientų tarpstacionarinị transportavimą tarp îstaigų gydymui užbaigti pagal gyvenamają vietą po SMP paslaugų suteikimo" turètų būti apmokama iš PSDF biudžeto, pasisako 87,5 proc. respondentų. Rezultatai nesiskiria statistiškai reikšmingai atsižvelgiant ị respondentų amžių, lytị, SPI steigèją, ASPI specialistų tipą ir ASPI lygmenị, tačiau skiriasi statistiškai reikšmingai $\left(\chi^{2}\right.$ kriterijus, $\left.p<0,05\right)$ atsižvelgiant ị stažą ( 7 pav.).

Nuomonei, kad už tarpstacionarinį transportavimą gydymui užbaigti pagal gyvenamają vietą turètų būti apmokama iš 
PSDF biudžeto, pritaria visi daugiau nei 20 metų darbo stažą turintys respondentai, kiti respondentai pagal darbo stažą šiai nuomonei pritaria mažiau. Šiuo metu už pacientų transportavimą tarp ligoninių gydymo įstaigos apmoka paslaugas teikiančioms GMP įstaigoms arba transportuoja pacientus savo lëšomis, atskiras apmokẻjimas iš TLK nèra skiriamas.

\section{Išvados}

1. Sklandų ir saugų pacientų tarpstacionarinio transportavimo vykdymą užtikrintų standarizuoto paciento būklès vertinimo protokolo įdiegimas asmens sveikatos priežiūros istaigose.

2. Paciento ar jo atstovo pasirašytas sutikimas, prieš transportuojant pacientą ị kitą ASPĮ, užtikrintų paciento teisių nepažeidžiamumą.

3. Atsakomybę už sprendimą transportuoti pacientą ị kitą ASPİ tūrètų prisiimti siunčiančios ịstaigos gydytojas. Tai pagreitintų ligų diagnostiką ir sumažintų konfliktinių situacijų tiek tarp skirtingų ASPI medicinos personalo, tiek ir su pacientu ar jo artimaisiais.

4. Tarpstacionarinio transportavimo teisinis reglamentavimas po SMP paslaugų suteikimo ị žemesnio lygio ASPĮ ar gydymui užbaigti pagal gyvenamają vietą užtikrintų efektyvų tretinio tarpstacionarinio transportavimo mechanizmą.

5. Pacientų tretinị tarpstacionarinị transportavimą (gydymui baigti pagal gyvenamają vietą) turètų vykdyti GMP tarnyba ar pačios gydymo ịstaigos, tačiau už šią paslaugą turètų būti atskirai apmokami iš PSDF biudžeto.

\section{Literatūra}

1. Fanara B, Manzon C, Barbot O, Desmettre T and Capellier G. Recommendations for the intra-hospital transport of critically ill patients. Critical Care, 2010; 14: R87.

https://doi.org/10.1186/cc9018

2. AIHW. Health expenditure Australia 2008-09. Australian Institute of Health and Welfare, 2010.

3. Samina TS, Gerber BS, Sharp LK. Traveling towards disease: transportation barriers to health care access. J Community Health 2013; 38(5): 976-993.

https://doi.org/10.1007/s10900-013-9681-1

4. Ward BW, Schiller JS, Goodman RA. Multiple chronic conditions among US adults: a 2012 update. Prev Chronic Dis, 2014;11:130389.

https://doi.org/10.5888/pcd11.130389

5. Bosk E, Veinot T, Iwashyna TJ. Which patients, and where: a qualitative study of patient transfers from community hospitals. Med Care, 2011; 49(6): 592-598. https://doi.org/10.1097/MLR.0b013e31820fb71b

6. Virketis G., Janušonis V., Kvekšaite V. Skubi medicinos pagalba: tarphospitaliniai pervežimai. Tiltai, 2016; 1,15-37. https://doi.org/10.15181/tbb.v73i1.1263

7. Health Outreach Partners. Overcoming obstacles to health care: transportation models that work. Oakland, 2014.

8. Schmalzried HD, Fallon LF. Reducing barriers associated with delivering health care services to migratory agricultural workers. Rural and Remote Health, 2012; 12:2088.

9. Wagner J, Iwashyna TJ, Kahn JM. Reasons underlying interhospital transfers to an academic medical intensive care unit. J Crit Care 2013; 28:202-8.

https://doi.org/10.1016/j.jcrc.2012.07.027

10. Marsico DJ. Medicaid expansion and premium assistance: the importance of non-emergency medical transportation (NEMT) to coordinated care for chronically ill patients. Community Transportation, 2014; 17-22.

11. Hains IM, Marks A, Georgiou A, Westbrook JI. Non-emergency patient transport: what are the quality and safety issues? International Journal for Quality in Health Care 2011; 23(1): 68-75.

https://doi.org/10.1093/intqhe/mzq076

12. Day D. Keeping patients safe during intrahospital transport. Critical care nurse, 2010; 30(4): 18-32. https://doi.org/10.4037/ccn2010446

13. Kulshrestha A, Singh J. Interhospital and intrahospital patient transfer: Recent concepts. Indian J Anaesth 2016; 60(7): 451-457.

https://doi.org/10.4103/0019-5049.186012

14. Whiteley S, Macartney I, Yorkshire JM, Barratt H, Binks R. Guidelines for the transport of the critically ill adult (3rd Edition 2011). The Intensive Care Society, 2011.

15. Kue R, Brown P, Ness C, Scheulen J. Adverse clinical events during intra hospital transport by a specialized team: a preliminary report. American Journal of Critical Care 2011; 20(2): 153-61. https://doi.org/10.4037/ajcc2011478

16. Audino MJ, Goodwill JA. Impacts of dialysis transportation on Florida's coordinated public transportation programs. National center for transit research, 2014.

17. Blakeman TC, Branson RD. Inter and intrahospital transport of the Critically Ill. Respiratory care, 2013; 58(6).

https://doi.org/10.4187/respcare.02404

18. Simon M. Medicaid non emergency medical transportation (NEMT) saves lives and money. Community Transportation, 2014; 11-12.

19. Watkins L, Hall C, Kring D. Hospital to home: a transition program for frail older adults. Professional Case Management, 2012; 17(3):117- 123; 124-125.

https://doi.org/10.1097/NCM.0b013e318243d6a7

20. Musumeci MB, Rudowitz R. Medicaid non emergency medical transportation: overview and key issues in medicaid expansion waivers. The Henry J. Kaiser Family Foundation Headquartersthe, 2016. 
21. Lietuvos Respublikos sveikatos apsaugos ministro $2016 \mathrm{~m}$. liepos $20 \mathrm{~d}$ įsakymas Nr. V-960 "Dẻl tęstinio aktyvaus gydymo paslaugos teikimo reikalavimų aprašo patvirtinimo". TAR, 2016-07-22; 20971.

22. Lietuvos Respublikos sveikatos apsaugos ministro $2014 \mathrm{~m}$. liepos 15 d. ísakymas Nr. V-810 "Dèl sveikatos sistemos plètros ir ligoninių tinklo konsolidavimo iki 2025 metų plano patvirtinimo". TAR, 2014, 2014-07-21, 2014-10411.

23. Lietuvos Respublikos sveikatos apsaugos ministro $2010 \mathrm{~m}$. gruodžio $27 \mathrm{~d}$. įsakymu Nr. V-1131 "Dèl Greitosios medicinos pagalbos teikimo ir išlaidų apmokèjimo tvarkos aprašo patvirtinimo" (Žin., 2010; 158-8058).

\section{THE PRINCIPLES OF SAFER AND MORE EFFECTIVE INTERHOSPITAL TRANSFER OF PATIENTS}

\section{G. Virketis, E. Krūminytė}

Key words: interhospital patients transfer, tertiary interhospital patients transfer, standardized protocol of assessment for condition of patients.

Summary

Interhospital patients transfer is an important part of patient's medical care widely used in the world including Lithuania. It is a separate health service activity substantiated by foreign researches. However, the extent, challenges and conditions of this activity are unknown in Lithuania. The principle mechanisms of safe and streamlined interhospital patients transfer among different levels of personal health care institutions will be discussed in the article.

The aim of the work is to observe and assess the opinion of the leaders and specialists of emergency medical care and in patient healthcare institutions about the current situation of patient interhospital transfer in Lithuania and to identify possible actions that could promote more effective and safer interhospital transfer.
Study object and methodology. Quantitative research was carried out by using a questionnaire survey method. 118 respondents participated in the survey. The respondents were the heads of inpatient departments of the personal healthcare institutions and of ambulance services units, the heads/assistants of the reanimation, intensive care and emergency department units.

Results and discussion. 83.9 percent of respondents claim that there are no standardized protocols of patients status assessment from one hospital to another. 53 percent agree that standardized protocols of patient's status assessment should be prepared and applied. The average response rate for the "dispatching physician" responsible for making a decision on transfer of a patient is statistically significantly higher than all the remaining answers in the meanings. More than two thirds of respondents (68.6 percent) agree that the consent of the patient (or representative) to transfer to another hospital is necessary. 73.1 percent respondents agree that after the provision of emergency service, it is expedient to regulate the further transfer to the place of residence. 45.2 percent agree that transfer should be conducted by the emergency department units. 87.5 percent respondents agree that "for interhospital patients transfer among institutions for the completion of home-based treatment after providing emergency services" should be paid from Compulsory Health Insurance Fund (CHIF).

Conclusions: The introduction of a standardized protocol of assessment for condition of patients would ensure safer interhospital patients transfer. The dispatching physician is responsible for determining the needs of patients transfer. The patient or his representative must be informed about the intended transfer in writing. Interhospital patients transfer service should be regulated and separately compensated from the CHIF budget.

Correspondence to: virketis@kul.1t

Gauta 2017-11-06 